\title{
Successional development of saltmarsh in two managed realignment areas in SE England, and prospects for saltmarsh restoration
}

\author{
R. G. Hughes ${ }^{1, *}$, P. W. Fletcher ${ }^{1}$, M. J. Hardy ${ }^{1,2}$ \\ ${ }^{1}$ School of Biological and Chemical Sciences, Queen Mary and Westfield College, University of London, London E1 4NS, UK \\ ${ }^{2}$ Present address: Department of Biological Sciences, University of Essex, Colchester CO4 3SQ, Essex, UK
}

\begin{abstract}
The primary successions of saltmarsh vegetation in 2 managed realignment sites in the Blackwater estuary (SE England), Tollesbury and Abbotts Hall, began with domination by the opportunistic annual species Salicornia europaea and Suaeda maritima. These species were gradually replaced by perennial species at the higher elevations, and a vertical zonation of dominant species was established in the order Salicornia europaea/Spartina anglica, Puccinellia maritima, Atriplex portulacoides and Elytrigia atherica, from low to high saltmarsh. Suaeda maritima became rarer and patchily distributed. Ordination analysis confirmed that after $12 \mathrm{yr}$ the new saltmarsh at Tollesbury was similar to the adjacent ancient saltmarsh. At Abbotts Hall the broadly similar successional sequence took only $5 \mathrm{yr}$. These were not facilitated successions - plants increasing the elevation of the sediment - because little sediment had accreted. Instead these were characteristic of tolerancetype successions, with the early opportunistic species having no apparent facilitative or inhibitive effect on the perennial species that arrived later and outcompeted them. If land at the appropriate elevation is provided by coastal realignment, saltmarsh develops to resemble the vegetation structure of ancient saltmarshes rapidly, with positive prospects for saltmarsh restoration. However, the erosion of saltmarsh vegetation that developed in historical realignment sites indicates that this benefit may be relatively short-term. Hence, long-term saltmarsh creation must also account for the processes causing saltmarsh erosion.
\end{abstract}

KEY WORDS: Saltmarsh succession · Zonation $\cdot$ Saltmarsh restoration · Managed realignment Resale or republication not permitted without written consent of the publisher

\section{INTRODUCTION}

Realignment of sea defences is increasingly used in the management of low-lying coastlines, particularly in Europe and North America, to reduce the cost of maintaining sea walls or to create new intertidal habitats for conservation purposes or in mitigation for habitats lost through development (Morgan \& Short 2002, Pethick 2002, Thom et al. 2002, Paramor \& Hughes 2005, Wolters et al. 2005, Byers \& Chmura 2007). In SE England, where local sea level is rising, mostly because the coast is undergoing isostatic subsidence, and a large area of saltmarsh is being eroded annually, several managed realignment areas have been constructed by breaching sea walls causing agricultural land to become intertidal (Wolters et al. 2005). The development of different habitats within realignment areas is of interest, particularly the formation of saltmarshes, and in the UK the government considered that the development of vegetation defined the success of a realignment scheme, on conservation and coastal defence criteria (Ministry of Agriculture, Fisheries and Food 1999). In North America, some saltmarshes in realignment sites developed rapidly to resemble old saltmarshes, in terms of community structure or ecological functioning, in only a few years (e.g. Morgan \& Short 2002, Thom et al. 2002, Byers \& Chmura 2007). In Europe, similar quantitative comparative studies have not been conducted, but Crooks et al. (2002) estimated that in SE England it would take about 100 yr before 
the vegetation in realignment areas resembled that of established saltmarshes.

Coastal saltmarshes are presumed to develop by facilitated succession, where sediments that accumulate in wave-sheltered environments are colonised by plants that promote further sediment accretion, by slowing water movement and stabilising the sediment with their roots (Chapman 1976, Long \& Mason 1983, Adam 1990, Davy et al. 2000). The increasing elevation of the sediment facilitates succession, as existing species are replaced by more competitive species less well adapted to the conditions associated with longer immersion in sea water. Facilitation succession may also occur because of increased nitrate content of accreting sediment (Olff et al. 1997), amelioration of the microclimate and soil salinity (Bertness 1991) and increased aeration of the anoxic sediment by early colonists (Callaway \& King 1996). There is short-term evidence that some species may increase sediment accretion and facilitate colonisation by other species (e.g. Callaway 1994, 1995, Castellanos et al. 1994, Langlois et al. 2003). However, Adam (1990) pointed out that definitive evidence for facilitated development of saltmarshes is lacking, primarily because it would require the analysis of vegetation change in the same location over a long time scale, and would need to differentiate the accretion of sediment caused by the plants from that allowed by the physical environment. Chapman (1976) estimated that the time taken for the vegetation to develop from Salicornia sp. domination to Aster tripolium domination could be about a century.

Saltmarsh plant species show a vertical zonation where, it is generally accepted, the lower limit of each species is determined by its tolerance to factors associated with inundation by sea water and the upper limit by biological interactions, particularly interspecific competition with plant species less able to tolerate inundation (Adam 1990). In many areas of SE England the lower limit of the saltmarsh is also restricted by bioturbation and herbivory by the invertebrate infauna (Gerdol \& Hughes 1993, Paramor \& Hughes 2004, $2005,2007)$. Vertical zonation of saltmarsh species may be a product of, and therefore indirect evidence for, facilitated succession, but Adam (1990), Gray (1992) and Davy et al. (2000) all urged caution in linking zonation to succession, as it may be more appropriate to consider zonation as a steady state reflecting the vertical environmental gradient. Roozen \& Westhoff (1985) examined succession of a saltmarsh for over $30 \mathrm{yr}$ and concluded that succession due to accretion was 'not (yet) visible' and that the zonation of the vegetation did not represent succession but differences in the abiotic environment related to elevation. Olff et al. (1997) described the changes to the vegetation on sediments accumulated over different time-scales at different elevations but also could not attribute the changes to succession or to the environment at the different elevations.

The potentially rapid development of new saltmarshes in managed realignment areas provides an opportunity to observe the processes of succession, and to investigate the relationship between succession and zonation. The present study reports the successional development of saltmarsh vegetation in 2 managed realignment sites, Tollesbury and Abbotts Hall, on the northern side of the Blackwater estuary (SE England) (Fig. 1). In both cases, reclaimed saltmarsh became intertidal again when sections of sea walls were removed. These were primary successions as no saltmarsh vegetation has occurred there for over 2 centuries. There were 2 main aims: (1) to examine the successional processes and determine if zonation is established by succession, and (2) to examine the rate of development of the new saltmarsh within the Tollesbury realignment site and its convergence to that of the adjacent ancient saltmarsh. The rate of development of the new saltmarsh at Abbotts Hall is compared to that at Tollesbury realignment, but not to a local reference saltmarsh. The plant nomenclature is that of Stace (1997), and following the first mention of the binomial name the generic name only is used for brevity, except where congeneric species are mentioned.

\section{MATERIALS AND METHODS}

Tollesbury. The Tollesbury managed realignment site was 21 ha of agricultural land which became intertidal up to a new sea wall when a breach was cut in the old sea wall in August 1995 (Fig. 1b). Up to $35 \mathrm{~cm}$ of sediment accretion has occurred in the lower areas of the site (Garbutt et al. 2008), which remain largely devoid of saltmarsh plants because of bioturbation and herbivory by the invertebrate infauna that colonised the accumulating sediment (Paramor \& Hughes 2005). The present study site was located on the higher land in the southeastern corner of the site (Fig. 1c) adjacent to area T3 of Wolters et al. (2008) with a similar profile, a mean slope of approximately $2.5 \%$ on the land and $50 \%$ on the new sea wall. Little apparent sediment accretion had occurred in this area (see also Wolters et al. 2008), but precise measurements (to the nearest $\mathrm{mm}$ ) (Garbutt et al. 2008) indicated a rise of the bed level of about $1 \mathrm{~cm}$ in $8 \mathrm{yr}$, which is within the margin of error using standard levelling equipment (see below). The substrate underlying the thin layer of new sediment remains as the hard compacted ex-agricultural soil and is devoid of infauna (Paramor \& Hughes 2005). 
a
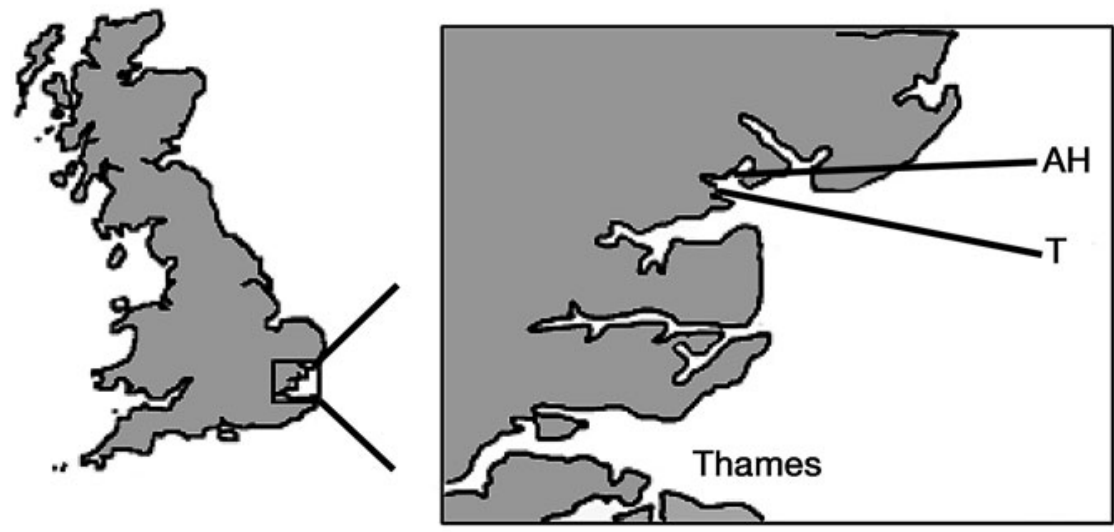

b

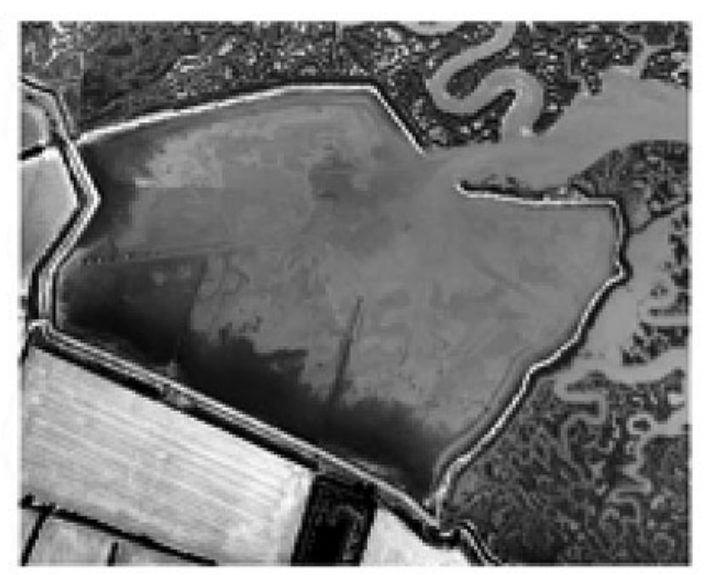

C

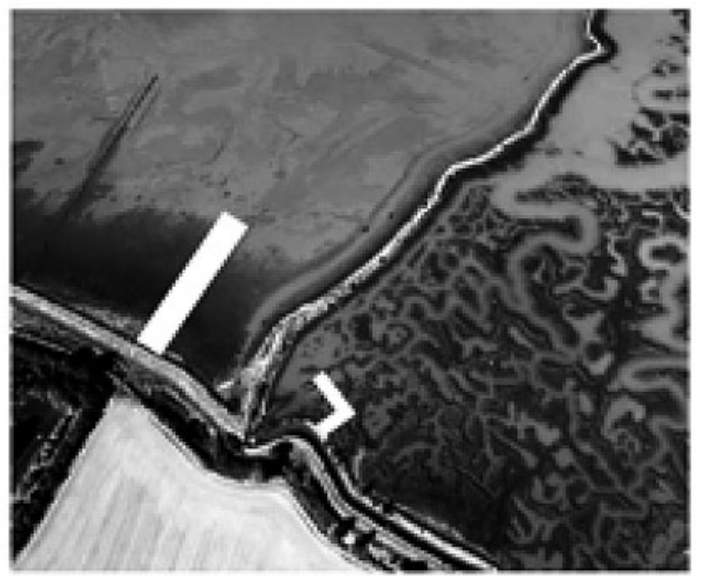

d

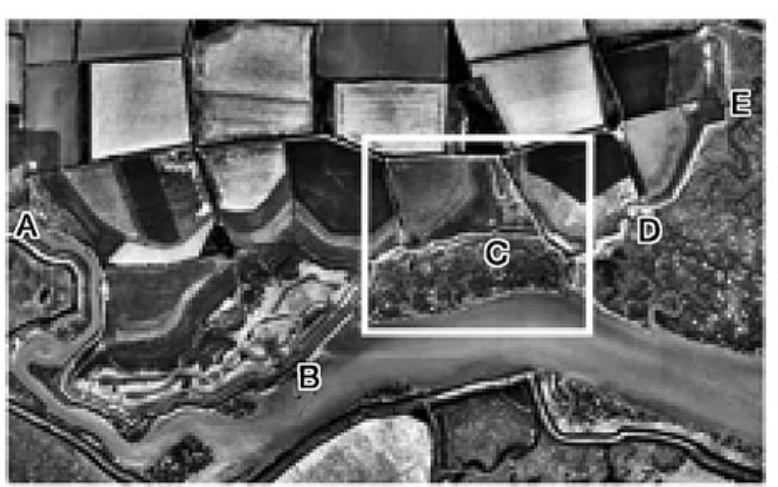

e

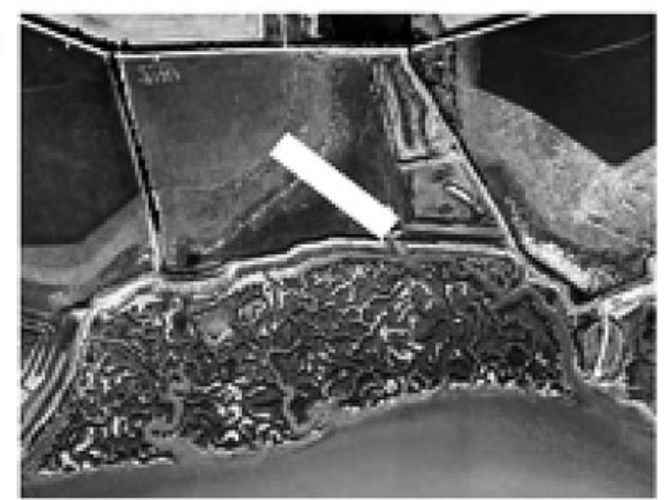

Fig. 1. (a) Location of the Tollesbury (T) and Abbotts Hall (AH) managed realignment sites in SE England. (b) Aerial view of the Tollesbury managed realignment site showing the development of new saltmarsh (dark upper areas). (c) Locations (white bars) of the transect areas in the SE corner of the Tollesbury realignment site and in the adjacent saltmarsh. (d) Aerial view of the Abbotts Hall site showing the 5 sea wall breaches (A-E) and the location of (e), the transect area (white bar) inside breach C.

(All aerial photographs from Google Maps @ 2008 Google-imagery, @ Digital Globe)

In the late summer of each year from 1996 onward a vertical transect was established consisting of 12 points separated by $20 \mathrm{~cm}$ vertical intervals located by use of an optical level and a graduated pole. The error in vertical measurements, estimated by repeated independent measurement of pairs of fixed points, was approximately $1 \mathrm{~cm}$. The elevations were fixed by surveying from a permanent reference post, the elevation of which was known relative to Ordnance Datum (OD), the national terrestrial reference datum used in the construction of the Tollesbury site. The transects extended from the lowest edge of the developing 
marsh (ignoring sporadic plants on the mudflat) up to the uppermost extent of sea couch grass Elytrigia atherica. The species above Elytrigia were grasses (e.g. Agrostis stolonifera and Phleum pratense) also common in terrestrial habitats, including the landward side of the new sea wall, and are not included here since their presence is probably not related to the seawater incursion. At each elevation the percentage cover of the plant species was recorded in each of eight $0.25 \mathrm{~m}^{2}$, non-contiguous quadrats placed randomly within $5 \mathrm{~m}$ either side of each transect point. The means for the species abundances in these 8 replicates are used here. As little sediment had accumulated, the transect points, levelled to the same elevations (1.4 to $3.6 \mathrm{~m}$ OD) each year, could have been in the same apparent locations from year to year, but there was deliberate variation in their horizontal locations.

The elevation data were later converted to Chart Datum (CD), the marine datum which approximates to the lowest local astronomical tide, and all elevation data given here are relative to $C D$. The relationship between the 2 data systems varies around the coast; at Tollesbury, CD is $2.15 \mathrm{~m}$ higher than OD (A. Garbutt pers. comm.). Mean high water neap tide level is approximately $3.80 \mathrm{~m} \mathrm{CD}$ and mean high water spring tide level is $5.10 \mathrm{~m}$ CD. The neap and spring tidal ranges are about 2.6 and $4.6 \mathrm{~m}$, respectively. The tidal curves at the 2 Tollesbury study sites were identical as measured on 4 separate occasions by concurrent observations of the immersion and emersion of graduated poles inserted into the sediment in both areas.

A similar vegetation survey was conducted in the adjacent ancient saltmarsh which is an extensive plateau excised by a complex and deep creek system (Fig. 1b,c). Pioneer zone plants are scarce in the saltmarsh, largely because the sediment at the appropriate level in the creeks is colonised by invertebrate infauna that prevent their colonisation (Paramor \& Hughes 2004). Consequently, the locations of the transects had to include rotational slumps, where sections of the eroding marsh had collapsed into the creeks. These slumps provide firm habitats for plants lower than the main saltmarsh plateau, but only temporarily because they erode slowly. The elevations of the saltmarsh transect points were cross-referenced by surveying from the realignment site across the intervening old sea wall. As in the realignment site, a transect line was established each year and 4 quadrats at each elevation were placed randomly on either side of each point. The lowest extent of the vegetation in the saltmarsh was $10 \mathrm{~cm}$ higher than in the realignment site, as there was no lower infauna-free sediment available, and the elevations of all the saltmarsh samples are displaced by $10 \mathrm{~cm}$ relative to the realignment samples. The saltmarsh here is not grazed by livestock, nor by grazing wildfowl such as Brent geese and widgeon, which do not occur in the inner saltmarsh, as confirmed by a lack of faeces. The similarity of the vegetation in the Tollesbury realignment site in 2007 was compared to that of the adjacent saltmarsh by ordination of species abundance data using detrended correspondence analysis (DECORANA) (Community Analysis Package, Pisces Conservation).

Abbotts Hall. The Abbotts Hall managed realignment site was created by breaching a seawall in 5 places to convert 80 ha of arable land into intertidal habitat (Fig. 1d) (Essex Wildlife Trust, www.essexwt. org.uk/sites/Abbotts $\% 20$ Hall $\% 20$ Farm.htm). Four of the 5 breaches (A-D) were created in October 2002 and breach E was cut in January 2003. The data reported here are from inside breach $\mathrm{C}$ (Fig. 1e) where the new intertidal area is separated from those inside the other breaches by higher land. The vertical distributions of the plant species were assessed, as described above, along a vertical transect established in a northwesterly direction up the existing slope from near the breach (Fig. 1). The vertical range of the samples was less than at Tollesbury because lower elevations were in a steep-sided eroding ditch near the breach, and the higher elevations were mown as part of the management of the grassland of the farm.

\section{RESULTS}

\section{Tollesbury}

The annual variations in the vertical distributions of the 6 abundant vascular plant species in the Tollesbury realignment site from 2000 to 2007 are shown in Fig. 2. Nine other species were present in the quadrats, but only sporadically and with low abundance. These were Atriplex littoralis, which was present only in 2000, Salicornia ramosissima, Sarcocornia perennis, Aster tripolium, Limonium vulgare, Spergularia media, Spergularia marina, Beta vulgaris and Inula crithmoides.

Initial colonisation in 1996 was dominated by Salicornia europaea (sensu stricto) and Suaeda maritima at very low densities (see also Garbutt et al. 2006, Wolters et al. 2008) and changes to the flora over the next 4 yr were mainly increases in the densities of these 2 species. Consequently, data prior to 2000 are not shown. In 2000, after 5 yr, the vegetation was dominated by Salicornia in the lower areas and Suaeda in the upper areas (Fig. 2). Puccinellia maritima, Atriplex portulacoides and Elytrigia atherica were present in low densities in the upper areas. By 2001, the 2 grass species Puccinellia and Elytrigia had increased in abundance, with the former dominating the middle areas of the developing saltmarsh and the latter domi- 

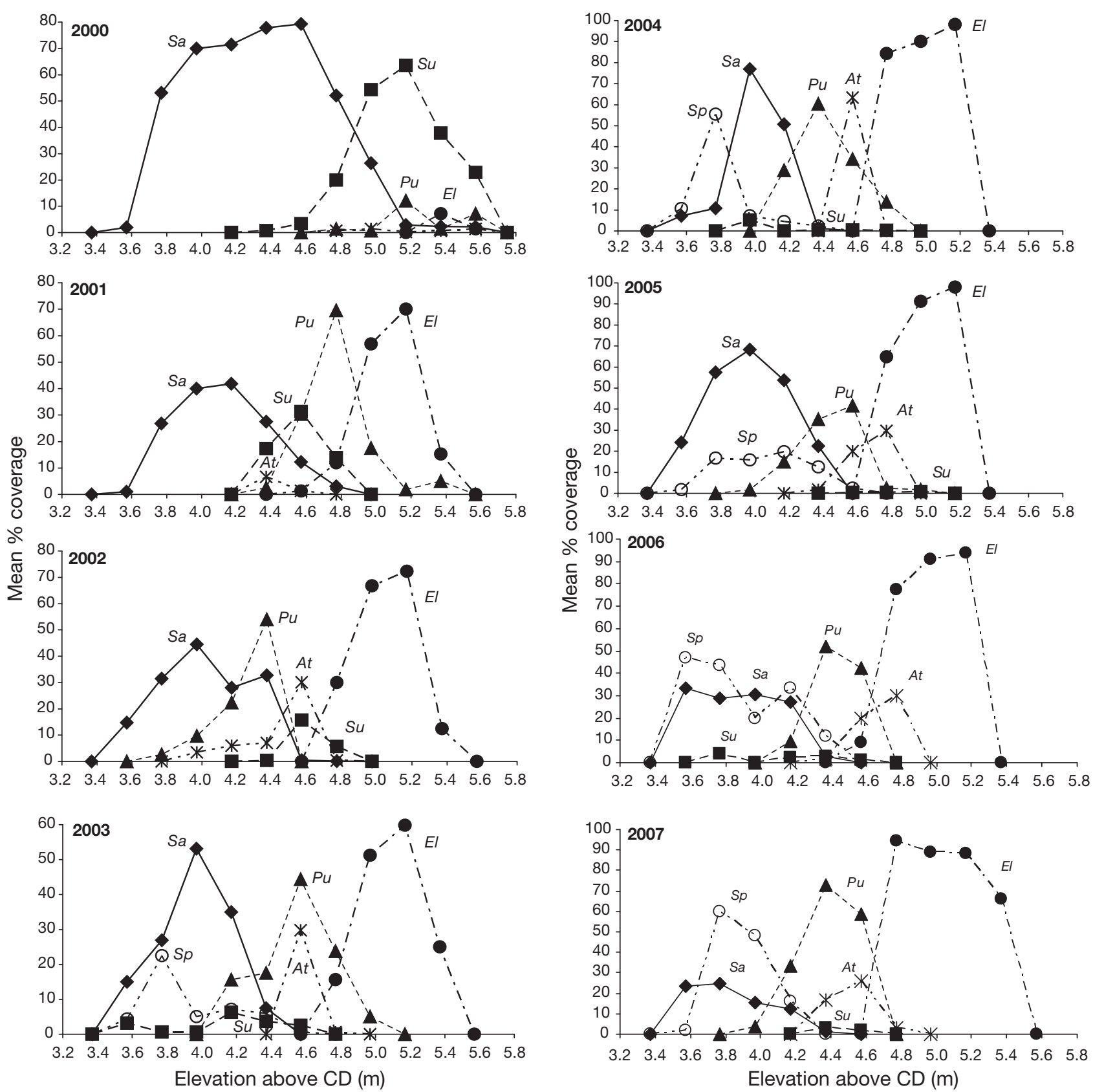

Fig. 2. Variations in the vertical distribution of the main plant species in the developing marsh in the Tollesbury managed realignment site from 2000 to 2007. Sa: Salicornia europaea; Su: Suaeda maritima, Sp: Spartina anglica; Pu: Puccinellia maritima; At: Atriplex portulacoides; El: Elytrigia atherica; CD: Chart Datum

nating the upper areas. Salicornia and Suaeda had moved downward and had become less abundant. By 2002, Spartina anglica appeared in the quadrats for the first time and Atriplex had increased in abundance, but the vertical distributions of the species had not changed significantly. In 2003, Spartina increased in abundance in the lower marsh, as did Suaeda, which decreased in abundance at $4.6 \mathrm{~m}$, where it was most abundant in the previous year. From 2004 onwards there were no further major changes in the vertical distributions of the species, except Elytrigia was now absent from $5.6 \mathrm{~m}$ where only terrestrial grasses were present. Suaeda became less abundant and Spartina further increased in abundance in the lower marsh.

The data from the surveys in the ancient saltmarsh were similar in all years and only the data for 2000 and 2007 are shown in Fig. 3. The only notable trend over the years was the gradual loss of Salicornia from the 
lowest elevations as the bases of the slumps eroded. There were variations in the abundance of Suaeda from year to year but this species always had a low abundance and there was no consistent trend in these changes.

The zonation achieved in the developing marsh became similar to that of the ancient saltmarsh, with domination of the lower marsh by Salicornia, the middle marsh by Puccinellia (which dominated the saltmarsh plateau) and Atriplex (which was most abundant at the creek edges in the saltmarsh) and the upper marsh by Elytrigia. However, Spartina was present in the lower parts in the realignment site but absent from the saltmarsh transects, although isolated plants were present elsewhere on the saltmarsh plateau. In the DECORANA analysis the samples from 2007 separated along the first axis according to their elevation and not their location (realignment or saltmarsh) (Fig. 4). A regression analysis of elevation (independent variable) against axis 1 score gave an $\mathrm{r}^{2}$ value of 0.89 . The cluster of 4 samples at the bottom left, with negative scores on axis 2, contains low sites dominated by Salicornia. Two other low samples from the realignment site $(3.6$ and $3.8 \mathrm{~m})$ separated from the others on axis 2 because they also contained Spartina. The samples from 4 to $4.5 \mathrm{~m}$ around the centre of axis 1 were dominated by Puccinellia. The sample from $4 \mathrm{~m}$ is to the left and high on axis 2 as it also had a relatively

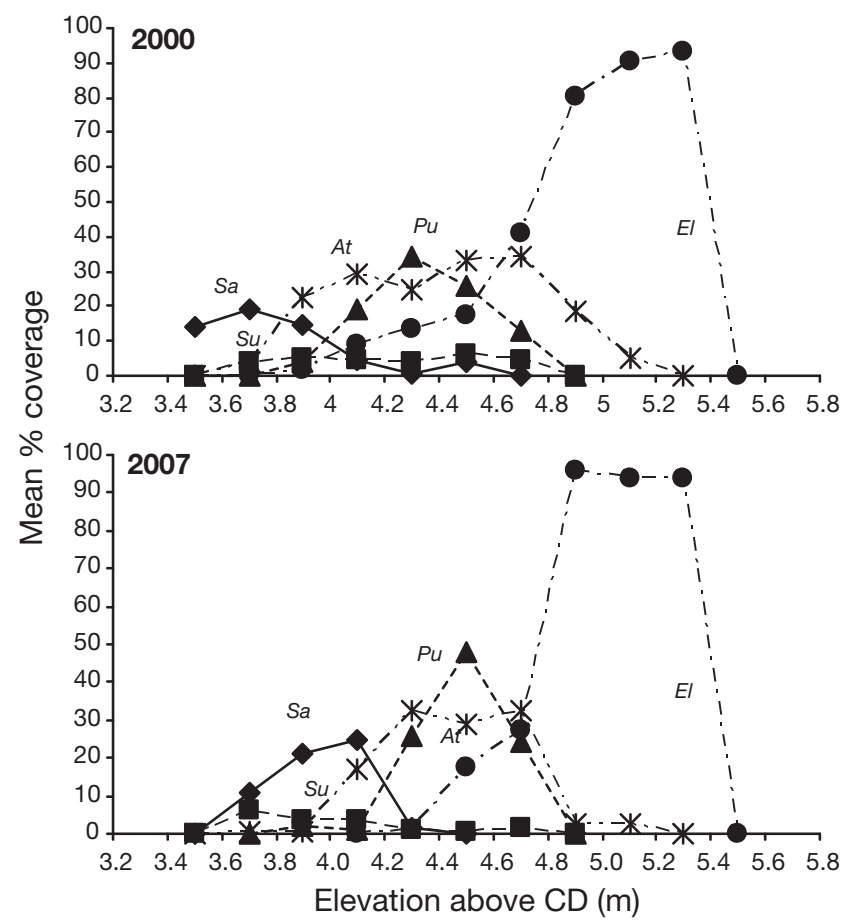

Fig. 3. Variations in the vertical distribution of the main plant species in the Tollesbury ancient saltmarsh in 2000 and 2007. Abbreviations are as in Fig. 2

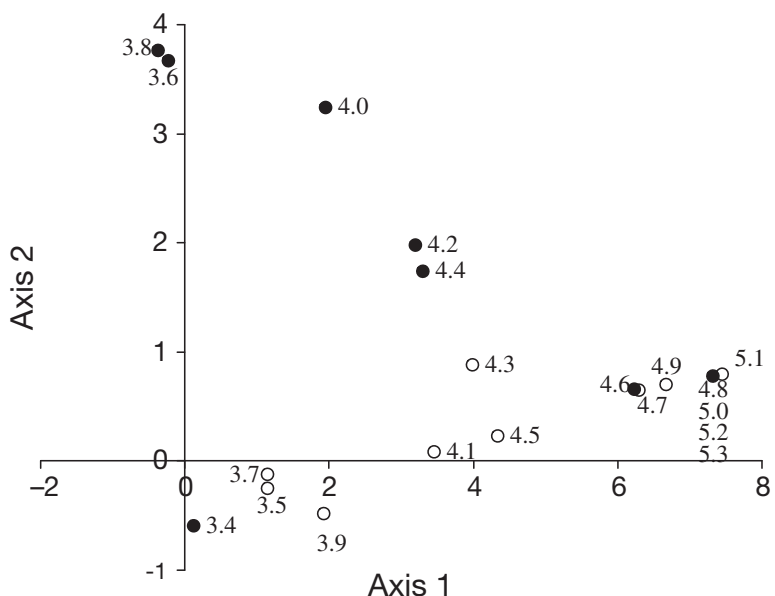

Fig. 4. DECORANA plot of the Tollesbury vegetation samples of 2007. The number of each site is its elevation ( $\mathrm{m}$ above Chart Datum). Samples from the realignment site are even numbers and filled circles and those from the adjacent ancient saltmarsh are odd numbers and open circles. The samples $4.8,5.0,5.2$ and 5.3 occupy the same location

high density of Spartina. Samples from 4.1 and $4.5 \mathrm{~m}$ were characterised by relatively high densities of Atriplex. The higher samples, from the marsh and realignment site, formed a tight cluster reflecting the dominance of Elytrigia (>90\% in all cases).

\section{Abbotts Hall}

In 2004, after $2 \mathrm{yr}$, the developing saltmarsh flora was dominated by Salicornia and Suaeda up to $4.9 \mathrm{~m}$ while Atriplex portulacoides and A. prostrata were dominant at 5.3 and $5.5 \mathrm{~m}$ above $\mathrm{CD}$, respectively (Fig. 5). In 2005, Puccinellia, present in low densities in 2004 became more abundant. Salicornia was abundant only below $4.3 \mathrm{~m}$, although it was present up to $5.1 \mathrm{~m}$. Suaeda dominated the middle of the developing marsh and A. portulacoides the upper levels. A. prostrata was no longer present but Spergularia media appeared in the upper samples. In 2006, a distinct vertical zonation was apparent with Salicornia, Suaeda, Puccinellia and A. portulacoides dominating respectively higher elevations of the marsh. At the upper levels, Spergularia increased in abundance and Elytrigia first appeared. In 2007, this zonation persisted but Salicornia and Suaeda declined in abundance and Puccinellia and A. portulacoides increased in abundance. Thus by 2007, after only $5 \mathrm{yr}$, the respective levels of the developing marsh were dominated by the same species as in the Tollesbury realignment site, but Spartina was not present. As at Tollesbury, Spartina occurred in the adjacent marshes but was not abundant. 

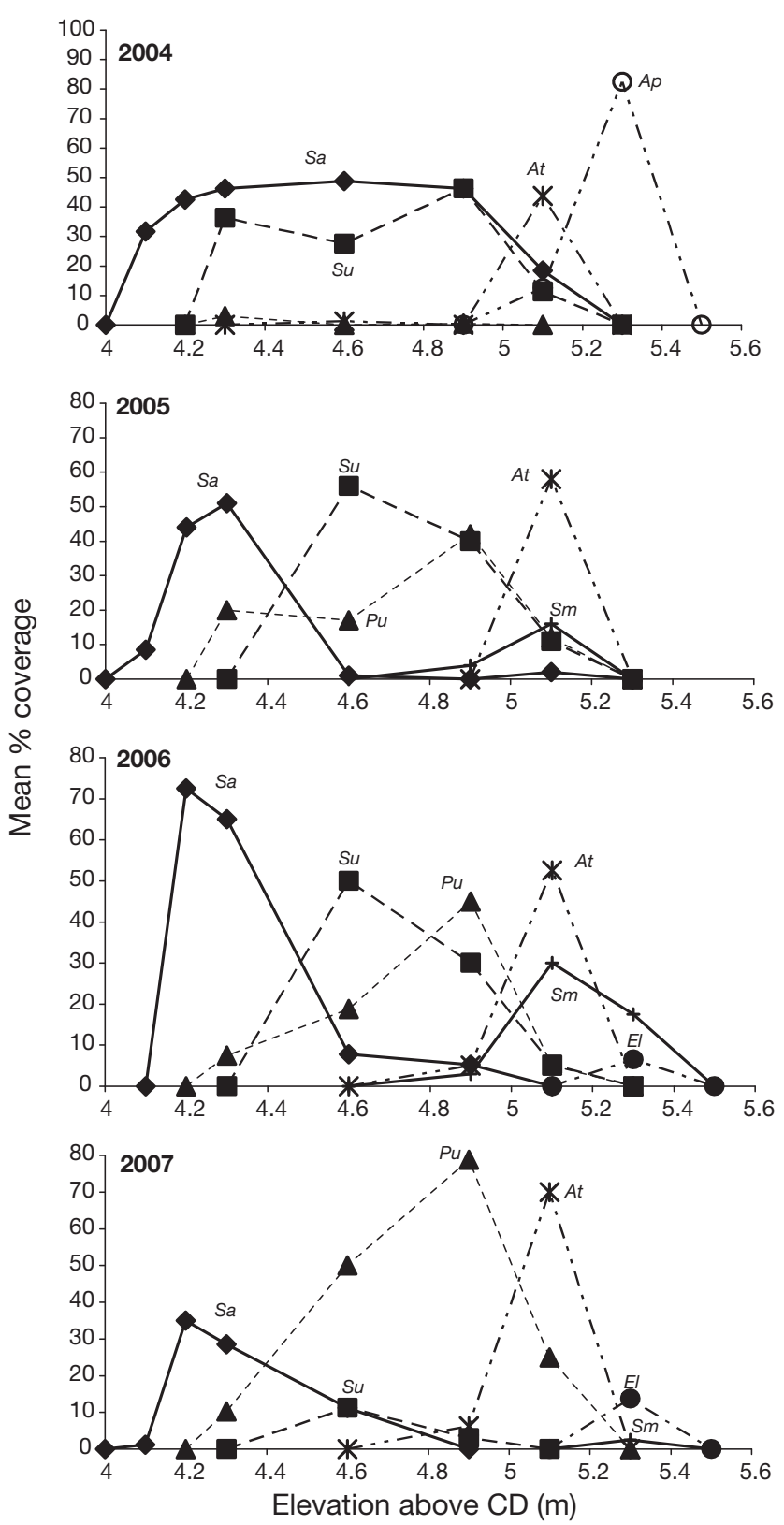

Fig. 5. Variations in the vertical distribution of the main plant species in the developing marsh in the Abbotts Hall managed realignment site from 2004 to 2007. Abbreviations are as in

Fig. 2. Ap: Atriplex prostrata; Sm: Spergularia media

\section{DISCUSSION}

\section{Succession}

Primary saltmarsh succession occurred on the newly intertidal land at the appropriate elevation for vascular plants in both realignment areas. Salicornia and Suaeda were the first to arrive and dominated until they were replaced at higher elevations by the com- petitively superior perennial species Puccinellia, Atriplex portulacoides and Elytrigia. This succession established a vertical zonation, predominantly in this sequence of species. Wolters et al. (2008) related the sequence of arrival of species in the Tollesbury realignment site to their salt tolerance, Salicornia and Suaeda being the most salt-tolerant. While there is this correlation, their early arrival is more a reflection of their high dispersal potential. These are relatively small, opportunistic annual species that are competitively subordinate with a high dispersal potential (as Wolters et al. 2008 also pointed out), and have evolved a relatively high salt tolerance which enables them to occupy the lowest areas of saltmarshes. Previous authors (Adam 1990, Gray 1992, Davy 2000) regarded the link between succession and zonation as a tenuous one, because of the absence of direct evidence, but in these 2 realignment sites zonation is the product of succession.

These successional changes were not due to facilitation by accretion of sediment, leading to a reduction in immersion periods, because very little accretion occurred in the upper areas of either realignment site where the vegetation developed (see also Wolters et al. 2008 for Tollesbury). At Tollesbury, Garbutt et al. (2008) recorded the elevation change of the developing saltmarsh to be about $1 \mathrm{~cm}$ over $8 \mathrm{yr}$. This small increase in elevation is about the same as the broad estimate of sea level rise of $1.5 \mathrm{~mm} \mathrm{yr}^{-1}$ for this coast, and therefore does not indicate a change in elevation related to local sea level.

Instead, these changes have the characteristics of tolerance-type succession (Connell \& Slatyer 1977), where the sequence of arrival of species is determined primarily by their dispersal potential and early colonists have little or no effect on later species, which come to dominate through a superior competitive ability. Connell \& Slatyer (1977) considered that inhibition of later species by the earliest colonists was an important factor in primary successions, but the rapid rate at which Salicornia and Suaeda were replaced, especially at Abbotts Hall, indicates that inhibition was not a significant factor here. This may be because in the spring the perennial plants can resume their growth while the next generation of Salicornia and Suaeda are germinating.

The reduction in the vertical range and abundance of Salicornia and Suaeda at both sites can be attributed to competitive exclusion rather than to an intolerable change to the habitat, because both species colonise temporary patches of bare substrata in the upper saltmarsh, here and in the nearby ancient saltmarshes. These bare areas are caused predominantly by rafts of filamentous algae deposited on the saltmarsh which smother the underlying vegetation. In SE England, 
Suaeda is often found only in such patches within the perennial vegetation (Fig. 3, authors' unpubl. data). Tessier et al. (2002) demonstrated experimentally that Suaeda colonised such disturbed areas but was gradually outcompeted by perennial species, and van Hulzen et al. (2006) reported that algal mats suppressed the growth of Spartina, allowing the competitively inferior Salicornia to coexist. Davy et al. (2000) referred to this process as facilitation, as the tall species facilitated colonisation by the opportunists by catching the algal mats, but perhaps these are better considered as disturbance events that start successional development on small spatial scales.

The successions reported here from the 2 managed realignment sites are artificial in that the instant availability of substrata over a relatively wide vertical range is not natural, apart from areas subject to seismic land subsidence (e.g. Shennan \& Hamilton 2006). Hence, the relevance of these observations to successions in natural saltmarshes is open to question. R. G. Hughes \& P. W. Fletcher (unpubl.) argue that most saltmarshes are not the product of facilitation succession, as is generally assumed, because they developed on land that was flooded by rising sea level, initially during the Holocene transgression and subsequently where coastlines are undergoing isostatic subsidence, as is the case in SE England. Consequently, the initial vegetation history of most ancient saltmarsh areas would be similar to that described in these realignment sites, where terrestrial plants killed by saltwater incursion are replaced either by the high marsh species (e.g. Elytrigia) directly or by pioneer zone species before being replaced relatively rapidly by high marsh species through tolerance-type succession.

Most saltmarshes maintain their elevation to keep pace with sea level rise (e.g. Goodman et al. 2007, Morris 2007) and it is expected that these new saltmarshes will also do so, and with little further change in vegetation now that they are similar to the ancient saltmarshes. The increase in elevation of approximately $1 \mathrm{~cm}$ in 8 yr recorded by Garbutt et al. (2008) at Tollesbury is consistent with the local sea level rise on this subsiding coast. However, over the long life-span of saltmarshes, tolerance-type successional processes, as described here, would occur following disturbances to the vegetation on small or intermediate scales.

\section{Implications for saltmarsh restoration}

The rate at which new saltmarsh becomes similar to existing saltmarshes is of current interest, and the rate of convergence is one measure of the success of restoration attempts (Morgan \& Short 2002, Thom et al. 2002, Byers \& Chmura 2007). Wolters et al. (2008), using species occurrence data, considered that the Tollesbury realignment site had reached the asymptotic saturation index appropriate for the local species pool after only 5 yr (by 2000). In the present study, these 14 species (see 'Results') were all recorded by 2000. However, analysis using species abundance, rather than occurrence, leads to the different conclusion that by 2000 the developing saltmarsh at Tollesbury, dominated by Salicornia and Suaeda, was different to the ancient saltmarsh. The close association of the 2007 samples from similar elevations from the 2 Tollesbury sites in the ordination analysis confirms that the developing marsh at Tollesbury was similar to the existing one after 12 yr. Further studies are required to establish if they are similar in ecological function (e.g. productivity). At Abbotts Hall, a similar zonation pattern of dominant species was achieved even more rapidly, after $5 \mathrm{yr}$, possibly because the incoming tide brought in more seeds as it flowed through a saltmarsh first, unlike at Tollesbury where the flood tide enters via the deeper and wider Tollesbury Creek.

The convergence of the new Tollesbury saltmarsh with the ancient saltmarsh was closest in the middle and upper elevations, dominated by Puccinellia and Elytrigia, respectively, but in the lower elevations there were notable differences, particularly in the abundance of Spartina in the Tollesbury realignment site compared to its scarcity in the ancient saltmarsh. The relatively slow colonisation of the Tollesbury realignment site by Spartina is notable as the species is often regarded as an opportunist. Since Spartina is scarce in the mature saltmarshes nearby, a low rate of supply of propagules may explain this. In addition, what is not apparent in the data from the vertical transects is the difference in horizontal extent of the pioneer zones. In SE England, the saltmarshes have experienced the loss of most of the pioneer zone vegetation (Burd 1992). In the Tollesbury ancient saltmarsh, the pioneer zone vegetation was present only on rotational slumps with steep slopes and covered only about $1 \mathrm{~m}$ in length. In contrast, in 2007 the Salicornia zones in the Tollesbury and Abbotts Hall managed realignment sites were approximately 40 and $20 \mathrm{~m}$ wide, respectively, because the land at the appropriate elevation was relatively flat. The development of extensive pioneer zone vegetation may, therefore, be regarded as a positive difference between the realignment sites and the ancient saltmarshes.

The rapid development of new saltmarsh in the Tollesbury and Abbotts Hall managed realignment areas, and at Orplands, another managed realignment site on the Blackwater estuary (Spencer et al. 2008), to converge with the community structure of ancient saltmarsh, is similar to the 10 to $20 \mathrm{yr}$ reported by Thom et al. (2002) in their review of saltmarsh creation in the 
United States. The saltmarshes developed much more rapidly than the estimate of Crooks et al. (2002), who concluded from observations of historical (unmanaged) realignment areas in SE England that about $100 \mathrm{yr}$ is required before the vegetation in realignment areas resembles that of the ancient marshes. However, coastal managers needing to create saltmarshes to compensate for the continuing losses of saltmarshes should be more pessimistic regarding the prospects for restoration by managed realignment in SE England. Most land behind the sea walls is reclaimed saltmarsh and is now lower than the existing saltmarshes because of land shrinkage and sea level rise since the land was reclaimed, up to several centuries ago (Hughes \& Paramor 2004). This low-lying land, when returned to the intertidal zone, accretes sediment but develops into mudflats colonised by bioturbating and herbivorous infauna which prevent development of vegetation (Gerdol \& Hughes 1993, Paramor \& Hughes 2005, 2007). Wolters et al. (2008) showed that in the Tollesbury realignment site, saltmarsh has not extended seaward after the initial $3 \mathrm{yr}$ despite sufficient sediment accretion. This was one lesson learned from the Tolles-
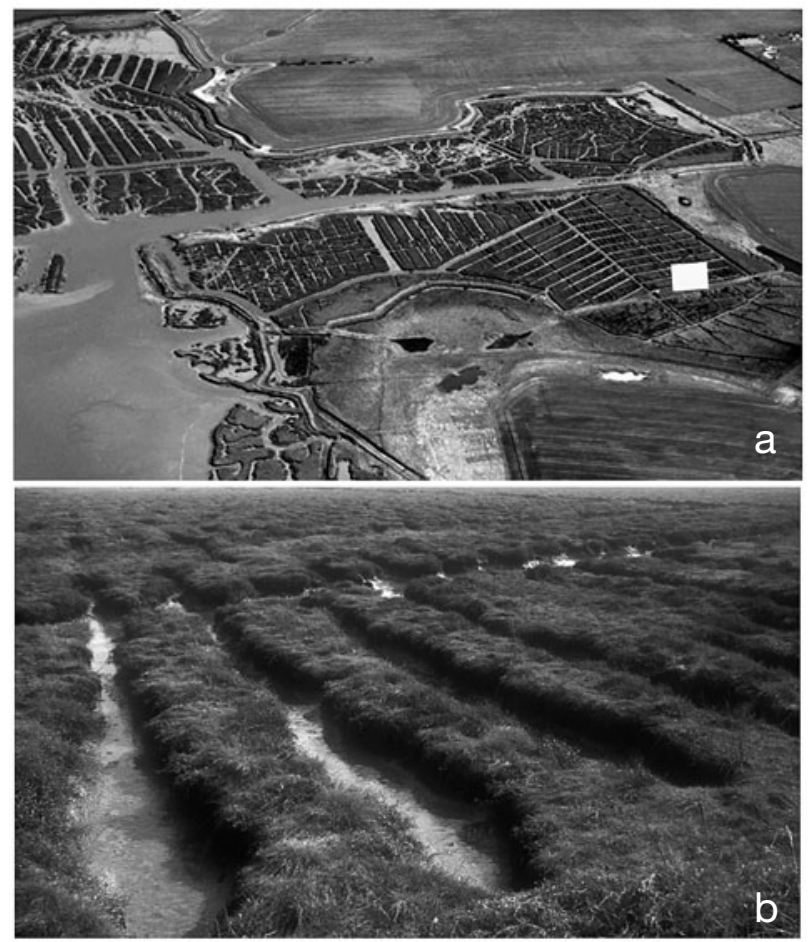

Fig. 6. (a) Aerial photograph of the historic coastal realignment at Brandy Hole Hullbridge, Crouch estuary, SE England, showing the rectilinear creeks that developed in the furrows of the flooded fields. A more natural creek pattern is developing in the area formed in 1897 (upper left). Photography from www.essex-estuaries.co.uk/roach_crouch/Scenes/ BrandyHole1.htm. The white square shows the area of (b), the smaller blind-ending eroding creeks that developed between the larger ones in the area flooded in 1953 bury experimental realignment scheme. In the 2006 managed realignment at Wallasea Island on the adjacent Crouch estuary, the landward strip where saltmarsh was required was first raised by recharge with dredged sediment contained within a constructed clay bund (www.defra.gov.uk/wildlife-countryside/ewd/ wallasea/index.htm). However, the new saltmarsh that develops on higher land becomes subject to the same erosive forces that are leading to extensive losses of the ancient saltmarshes (Paramor \& Hughes 2004). A typical example of the loss of historically created saltmarsh through internal creek erosion is Brandy Hole near the head of the Crouch estuary (Fig. 6). Here, as in many other similar sites, this erosion often appears as a rectilinear pattern of creeks, at a higher density than the natural saltmarshes (Crooks et al. 2002). This pattern arises because the furrows between ridges, which were created on the reclaimed land to improve drainage, become the focus for erosive flow, particularly on ebb tides (authors' unpubl. data). The dimensions of these creeks are related to their age; those in saltmarshes created after a storm in 1897 are up to several metres wide, and often little vegetation remains, while those created by the 1953 storm are smaller, but even here about $40 \%$ of the created saltmarsh can be lost. Consequently, management of saltmarshes, including in realignment areas, needs to be considered in the long-term (century scale) and needs to address the fundamental reasons for their continuing erosion.

Acknowledgements. We thank the Essex Wildlife Trust, particularly D. Smart and A. May, for their cooperation and access to Abbotts Hall

\section{LITERATURE CITED}

Adam P (1990) Saltmarsh ecology. Cambridge University Press, Cambridge

> Bertness MD (1991) Interspecific interactions among high marsh perennials in a New England saltmarsh. Ecology 72:125-137

Burd F (1992) Erosion and vegetation change on the saltmarshes of Essex and north Kent between 1973 and 1988. Research and Survey in Nature Conservation 42, Nature Conservancy Council, Peterborough

Byers SE, Chmura GL (2007) Salt marsh vegetation recovery on the Bay of Fundy. Estuaries Coasts 30:869-877

Callaway RM (1994) Facilitative and interfering effects of Arthrocnemum subterminale on winter annuals. Ecology 75:681-686

Callaway RM (1995) Positive interactions among plants. Bot Rev 61:306-349

Callaway RM, King L (1996) Temperature-driven variation in substrate oxygenation and the balance of competition and facilitation. Ecology 77:1189-1195

Castellanos EM, Figueroa ME, Davy AJ (1994) Nucleation and facilitation in saltmarsh succession: interactions between Spartina maritima and Arthrocnemum perenne. J Ecol 82:239-248 
Chapman VJ (1976) Coastal vegetation. Pergamon Press, Oxford

Connell JH, Slatyer RO (1977) Mechanism of succession in natural communities and their role in community stability and organization. Am Nat 111:1119-1144

Crooks S, Schutten J, Sheern GD, Pye K, Davy AJ (2002) Drainage and elevation as factors in the restoration of saltmarsh in Britain. Restor Ecol 10:591-602

Davy AJ (2000) Development and structure of salt marshes: community patterns in time and space. In: Weinstein MP, Kreeger DA (eds) Concepts and controversies in tidal marsh ecology. Kluwer Academic Publishers, Dordrecht, p 137-156

Davy AJ, Costa SBC, Yallop AR, Proudfoot AM, Mohamed MF (2000) Biotic interactions in plant communities of saltmarshes. In: Sherwood BR, Gardiner BG, Harris T (eds) British saltmarshes. The Linnean Society, London, p 110-127

Garbutt RA, Reading CJ, Wolters M, Gray AJ, Rothery P (2006) Monitoring the development of intertidal habitats on former agricultural land after the managed realignment of coastal defences at Tollesbury, Essex, UK. Mar Pollut Bull 53:155-164

Garbutt RA, Reading CJ, Turk A, Yates M, Rothery P (2008) Botanical and sediment monitoring of the Tollesbury managed realignment site and adjacent saltmarshes. In: Managed realignment at Tollesbury. R\&D Technical Report FD 1922/TR, Department for Environment, Food and Rural Affairs, London, available at http://randd.defra.gov.uk/ Document.aspx? Document=FD1922_7435_TRP.pdf

Gerdol V, Hughes RG (1993) Effect of the amphipod Corophium volutator on the colonisation of mud by the halophyte Salicornia europaea. Mar Ecol Prog Ser 97: 61-69

Goodman JE, Wood ME, Gehrels WR (2007) A 17-yr record of sediment accretion in the salt marshes of Maine (USA). Mar Geol 242:109-121

Gray AJ (1992) Saltmarsh plant ecology: zonation and succession revisited. In: Allen JRL, Pye K (eds) Saltmarshes: morphodynamics, conservation and engineering significance. Cambridge University Press, Cambridge, p 63-79

> Hughes RG, Paramor OAL (2004) On the loss of saltmarshes in south-east England and methods for their restoration. J Appl Ecol 41:440-448

Langlois E, Bonis A, Bouzille JB (2003) Sediment and plant dynamics in saltmarshes pioneer zone: Puccinellia maritima as a key species? Estuar Coast Shelf Sci 56:239-249

Long SP, Mason CF (1983) Saltmarsh ecology. Blackie, Glasgow

Ministry of Agriculture, Fisheries and Food (1999) Tollesbury managed realignment experimental site. Summary report of research and other activities, 1994-96. Ministry of Agriculture, Fisheries and Food, London

Morgan PA, Short FT (2002) Using functional trajectories to

Editorial responsibility: Mike Elliot,

Hull, UK track constructed salt marsh development in the Great Bay Estuary, Maine/New Hampshire, USA. Restor Ecol 10: 461-473

Morris JT (2007) Ecological engineering in intertidal saltmarshes. Hydrobiologia 577:161-168

Olff H, De Leeuw J, Bakker JP, Platerink RJ, van Wijnens HJ (1997) Vegetation succession and herbivory in a salt marsh: changes induced by sea level rise and silt deposition along an elevational gradient. J Ecol 85:799-814

Paramor OAL, Hughes RG (2004) The effects of bioturbation and herbivory by the polychaete Nereis diversicolor on loss of saltmarsh in SE England. J Appl Ecol 41:449-463

$>$ Paramor OAL, Hughes RG (2005) Effects of the invertebrate infauna on early saltmarsh plant colonization of managed realignments in south-east England. Mar Ecol Prog Ser 303:61-71

Paramor OAL, Hughes RG (2007) Restriction of Spartina anglica (C. E. Hubbard) marsh development by the infaunal polychaete Nereis diversicolor (O. F. Müller). Estuar Coast Shelf Sci 71:202-209

Pethick J (2002) Estuarine and tidal wetland restoration in the United Kingdom: policy versus practice. Restor Ecol 10:431-437

Roozen AJM, Westhoff V (1985) A study on long-term saltmarsh succession using permanent plots. Vegetatio 61: $23-32$

Shennan I, Hamilton S (2006) Coseismic and pre-seismic subsidence associated with great earthquakes in Alaska. Quat Sci Rev 25:1-8

- Spencer KL, Cundy AB, Davies-Hearn S, Hughes RG, Turner S, MacLeod CL (2008) Physicochemical changes in sediments at Orplands Farm, Essex, UK following 8 years of managed realignment. Estuar Coast Shelf Sci 76:608-619

Stace C (1997) New Flora of the British Isles, 2nd edn. Cambridge University Press, Cambridge

Tessier M, Gloaguen JC, Bouchard V (2002) The role of spatio-temporal heterogeneity in the establishment and maintenance of Suaeda maritima in slat marshes. J Veg Sci 13: $115-122$

Thom RM, Zeigler R, Borde AB (2002) Floristic development patterns in a restored Elk River estuarine marsh, Grays Harbor, Washington. Restor Ecol 10:487-496

> van Hulzen JB, van Soelen J, Herman PMJ, Bouma TJ (2006) The significance of spatial and temporal patterns of algal mat deposition in structuring salt marsh vegetation. J Veg Sci 17:291-298

Wolters M, Garbutt A, Bakker JP (2005) Salt-marsh restoration: evaluating the success of de-embankments in northwest Europe. Biol Conserv 123:249-268

Wolters M, Garbutt A, Bekker RM, Bakker JP, Carey PD (2008) Restoration of saltmarsh vegetation in relation to site suitability, species pool and dispersal traits. J Appl Ecol 45:904-912

Submitted: August 22, 2008; Accepted: March 23, 2009

Proofs received from author(s): May 20, 2009 